TTR

Traduction, terminologie, rédaction

\title{
Algorithmic Mimesis: Translation, Technology, Resistance
}

\section{Stephen Slessor et Anne Sophie Voyer}

Volume 29, numéro 2, 2e semestre 2016

Translation and Power: Countertactics

La traduction et le pouvoir : la contre-tactique

URI : https://id.erudit.org/iderudit/1051016ar

DOI : https://doi.org/10.7202/1051016ar

Aller au sommaire du numéro

\section{Éditeur(s)}

Association canadienne de traductologie

ISSN

0835-8443 (imprimé)

1708-2188 (numérique)

Découvrir la revue

Citer cet article

Slessor, S. \& Voyer, A. S. (2016). Algorithmic Mimesis: Translation, Technology, Resistance. TTR, 29(2), 129-154. https://doi.org/10.7202/1051016ar

\section{Résumé de l'article}

Les technologies de la traduction posent souvent la traduction comme un processus simple de transfert linguistique d'un code à un autre, ou bien comme une sélection de segments correspondants à partir d'une base de données. La proéminence de ces technologies à l'ère numérique a renouvelé les discussions traductologiques portant sur la fidélité et l'équivalence. L'attention critique accordée aux contextes culturels et textuels plus vastes, mise de l'avant par le tournant culturel, semble risquer de disparaître dans le cyberespace. En utilisant les faiblesses de la technologie comme catalyseurs pour leurs oeuvres créatives, certains artistes de l'ère numérique tels que Urayoán Noel et Malinda Kathleen Reese canalisent les déficiences de manière productive dans leur art, révélant ainsi les potentiels insoupçonnés des technologies numériques. Une telle vision de la traduction comme création contredit le lieu commun voulant que la traduction ne soit qu'un acte scientifique de pur transfert sémantique produisant une illusion d'identité entre source et cible. Faisant écho à la notion de « bricolage » avancée par Lévi-Strauss - c'est-à-dire le moyen par lequel les matériaux culturels sont récupérés et recombinés pour créer de nouveaux contenus - Reese et Noel se libèrent du joug sémantique de l'identité par l'utilisation de technologies dans le but de trouver de nouvelles méthodes de récupération et transformation du matériel linguistique et culturel. Leur art nous permet de re-conceptualiser la traduction de manière à aller au-delà des notions fixes gouvernant ce qu'une traduction devrait être, ou faire, en termes de fidélité ou d'équivalence. Leur utilisation ludique, détournée, de la traduction automatique et de la reconnaissance vocale permet une analyse critique de la tension entre l'universel et le particulier en ce qui concerne l'acte traductif. Elle utilise des formes d'expérimentation formelle et d'humour pour résister aux dynamiques traditionnelles du pouvoir.
Ce document est protégé par la loi sur le droit d'auteur. L’utilisation des services d'Érudit (y compris la reproduction) est assujettie à sa politique d'utilisation que vous pouvez consulter en ligne.

https://apropos.erudit.org/fr/usagers/politique-dutilisation/ 


\title{
Algorithmic Mimesis: Translation, Technology, Resistance
}

\author{
Stephen Slessor and Anne Sophie Voyer ${ }^{1}$ \\ University of Ottawa
}

\begin{abstract}
Translation technologies often figure translation as a simple process of linguistic transfer from one code to another or as a question of selecting the correct matching segments from a database. The prominence of such technologies in the digital age has thus renewed discussions of fidelity and equivalence for translators. The critical attention given to broader cultural and textual contexts that came into focus with the cultural turn seems at risk of disappearing into cyberspace. However, the ongoing proliferation of textual production and reproduction also foregrounds the possibilities of variability and difference in repetition. Using the foibles of technology as catalysts for their own creative ventures, digital-age artists such as Urayoán Noel and Malinda Kathleen Reese channel deficiencies productively in their art, revealing the unsuspected potentials of digital technologies. Such a view of translation as creation challenges the commonplace notion that translation is a scientific act of "carrying across," a purely semantic transfer that results in the (illusion of) identicality of source and target. Echoing Lévi-Strauss's notion of "bricolage" - the means by which people retrieve and recombine cultural materials to create new content-Reese and Noel shatter the semantic shackles of identicality by using technology to retrieve and transform the material scraps of language and culture. Their art helps us reconceptualize translation and go beyond fixed notions of what a translation should be or do in terms of fidelity and equivalence. Their playful misuse of machine translation and voice-recognition software allows for a critical analysis of the tension between the universal and the particular as it relates to the act of translation, and does so in a way that uses formal experimentation and humour to resist traditional power dynamics.
\end{abstract}

Keywords: experimental translation, machine translation, voice recognition, bricolage, humour

1. The authors consider themselves equal co-producers of the present article. As such, no hierarchy should be implied by the order of their names in the heading. 


\section{Résumé}

Les technologies de la traduction posent souvent la traduction comme un processus simple de transfert linguistique d'un code à un autre, ou bien comme une sélection de segments correspondants à partir d'une base de données. La proéminence de ces technologies à lère numérique a renouvelé les discussions traductologiques portant sur la fidélité et l'équivalence. L'attention critique accordée aux contextes culturels et textuels plus vastes, mise de l'avant par le tournant culturel, semble risquer de disparaître dans le cyberespace. En utilisant les faiblesses de la technologie comme catalyseurs pour leurs œuvres créatives, certains artistes de lère numérique tels que Urayoán Noel et Malinda Kathleen Reese canalisent les déficiences de manière productive dans leur art, révélant ainsi les potentiels insoupçonnés des technologies numériques. Une telle vision de la traduction comme création contredit le lieu commun voulant que la traduction ne soit qu'un acte scientifique de pur transfert sémantique produisant une illusion d'identité entre source et cible. Faisant écho à la notion de "bricolage» avancée par Lévi-Strauss - c'est-à-dire le moyen par lequel les matériaux culturels sont récupérés et recombinés pour créer de nouveaux contenus Reese et Noel se libèrent du joug sémantique de l'identité par l'utilisation de technologies dans le but de trouver de nouvelles méthodes de récupération et transformation du matériel linguistique et culturel. Leur art nous permet de re-conceptualiser la traduction de manière à aller au-delà des notions fixes gouvernant ce qu'une traduction devrait être, ou faire, en termes de fidélité ou d'équivalence. Leur utilisation ludique, détournée, de la traduction automatique et de la reconnaissance vocale permet une analyse critique de la tension entre l'universel et le particulier en ce qui concerne l'acte traductif. Elle utilise des formes d'expérimentation formelle et d'humour pour résister aux dynamiques traditionnelles du pouvoir.

Mots-clés : traduction expérimentale, traduction automatique, reconnaissance vocale, bricolage, humour

Variability is the signature tune of the translator's art. What is more, it is the very variable nature of translation practice that places it at the centre of the profound changes in the culture of the digital age.

(Cronin, 2013a, p. 87)

The idea that the human race is in the midst of a fundamental cultural shift as we move from the mechanical age into the digital age is now a commonplace. In his 2013 monograph Translation in the Digital Age, Michael Cronin argues that translation, by its very nature, is poised to take a leading role in the new digital reality. At the centre of the ongoing cultural shift, at least as it relates to translators, is the transition from what Cronin refers to 
as a "semantic regime of identicality" to a "paradigm of variability" (2013a, p. 5). He argues that the emphasis on identicality began with the Renaissance philological concern for the stabilization of authorship and with the ability to mass produce identical texts on a printing press. An ideal of identicality has long permeated discussions of translation, most prevalently in the metaphor of translating as "carrying across" a so-called essence of the source text into the target. We also see it in ever-present terms such as accuracy, fidelity, betrayal, and misrepresentation. George Steiner's seminal work on translation, After Babel, describes these age-old concerns, in particular in his assertion that, on some level, "all theories of translation-formal, pragmatic, chronological-are only variants of a single, inescapable question. In what ways can or ought fidelity to be achieved?”(1998 [1975], p. 261).

Translation studies has, of course, continued to evolve in recent decades. With the "cultural turn" of the 1980s and 1990s (see Snell-Hornby, 2006), a shift in focus occurred-from fidelity, philological consistency, linguistic code, and one-for-one equivalence to one centred on the broader cultural and textual contexts - including the underlying power dynamics — of acts of translating. This attention to context has given researchers and theorists a new critical eye with which to examine translational phenomena. Notably, these changing perspectives help address the main problem with the tradition of viewing translation in terms of identicality - the fact that translation never achieves it in practice. Take any source text, give it to 30 translators, and the result will likely be 30 different translations. The reasons for the differences vary widely, from translators' linguistic preferences to the purpose of a given text in a given situation to the ideological stances of those who translate and publish, along with a myriad of other factors.

The digital age and its upheavals have brought forth new ways of thinking about the role of translators, communication, and even language itself. The advent of computers has led to significant and ongoing changes in the way text is composed and published. The enduring mark of unchanging print on paper has given way to a world of endless revision. José Ramón Bau Gil and Anthony Pym describe what this has meant for many translators:

Texts on the web are constantly being updated, as is our software. We are sometimes called on to render no more 
than the updates or adaptations. Our translations may thus be expected to move away from the ideal of equivalence between fixed texts, becoming more like one set of revisions among many. (2006, p. 6)

For Cronin, this type of textual variation goes hand in hand with the digital age and what he calls the "paradigm of variability" (2013a, p. 5). Such a paradigm is perhaps most evident in digital publishing, which allows for the "serial" reproduction of text in successive versions with minor or major variations and at little additional cost. However, the notions of serial revision or difference in repetition are not always present in discussions of translation technology. Instead, the ghosts of identicality remain. Specialized tools offer up "equivalent" segments to timepressed translators. Machine translation (MT), in particular, figures translation as a simple process of linguistic transfer from one code to another, obscuring the fraught nature of cultural transformation and the power structures that govern the process. The attention to broader cultural and textual contexts that came into focus with the cultural turn seems at risk of disappearing into cyberspace.

Cronin recognizes the tension between the variability promised by the digital age and the ghosts of identicality. He describes the instrumental vision of translation projected by MT and most online translation services as "transitive" (2013a, pp. 49-50), one in which all translatorial action is seen as having an explicit object-achieving the "correct" translation. However, Cronin notes that in reality, translation never works that way, arguing that the process is often more important, and that there are always unexpected effects. As such, the outcome is necessarily indeterminate. He further argues that the "tyranny of transitivity" is challenged by technologies themselves (ibid., p. 53). Translators generally have little formal training on the technologies; therefore, the ways in which they may employ them are fundamentally unpredictable. What translators do with technology does not always jibe with instrumentalist expectations, instead revealing "unsuspected potentials" of the technologies (ibid.).

In the spirit of exploring the unsuspected potentials of translation technologies, we would like to examine the work of two digital-age artists-Malinda Kathleen Reese and Urayoán Noelwho, we would argue, revel in the "intransitivity" of their translation 
processes. They test the limits of convertibility by granting computers a level of control of the process, but in a way that highlights the unpredictability of the results. Their playful misuse of MT and voice-recognition software allows for a critical analysis of the tension between the universal and the particular as it relates to the act of translation, and does so in a way that uses formal experimentation and humour to resist traditional power dynamics. We will consider how Reese and Noel harness technology for different creative ends and how each consciously intervenes in the translation process by playing with the linguistic material of the Other for their own purposes. Claude Lévi-Strauss's notion of "bricolage" (1966 [1962]) will provide a framework of reference for theoretical reflection.

\section{Translation Technologies, Context, and Power}

Lawrence Venuti stresses the recurring patterns of dominance inherent to the realms of culture and language by stating that "any language use is [...] a site of power relationships because a language $[. .$.$] is a specific conjuncture of a major form holding$ sway over minor variables" (1998, p. 10). Translation, as a form of cross-cultural communication, often embodies this complex power dynamics, and the study of translation practices, especially since the 1990s, has emphasized the importance of attending to the larger issues of context, history, and convention. Proper contextualization is vital to the process of translation, as it brings together the collective contexts from which a text emerges, under which the act of translation takes place, and into which a text is transposed. Yet, recontextualization, so crucial to the success of a translation, is rarely achieved by translation technologies, which, since their earliest iterations, have divided up coherent, cohesive units of text into decontextualized word strings demarcated by punctuation marks. This segmentation process itself may appear somewhat arbitrary, and relies on the implication that units of lucid thought most often begin with a capital letter and end with a period. While algorithms are increasingly capable of integrating vast quantities of data from a wide array of sources, computers are still largely unable to precisely evaluate relevance, which, in the case of MT, means that output may leave readers wanting.

There is a general consensus that MT output, as a rule, requires human revision. Indeed, the human touch is perhaps the sine qua non of computer-aided translation; without it, the results 
will be critiqued for their lack of accuracy and nuance. MT's less-than-flattering reputation extends from translation scholars to the general public of active users. Though MT has improved significantly in the last decade, results are still far from perfect. Sheila Castilho et al. note that "different theories and practices for [MT] have come and gone, with each new wave generating great excitement and anticipation in the field," yet "[f]rom the first commercial rule-based systems to more recent statistical models, there has [...] generally been great discrepancy between the high expectation of what MT should accomplish and what it is actually able to deliver" (2017, p. 109). Even state-of-the-art systems - including the much-vaunted neural machine translation models ${ }^{2}$ - cannot yet render target texts of high enough quality that one would ever consider them publication-ready. At best, MT output requires light post-editing by a human being; at worst, it ends up completely distorted.

Alan Melby has suggested that MT may not even be concerned with producing perfect translations:

It has often been assumed that for a translation to be useful it must be of sufficiently high quality to be comparable to the work of a professional human translator. Not so. Lowquality MT that is produced quickly and used only to get an indication of the content of the original text and which is then often discarded is sometimes called "indicative translation." Surprisingly, indicative translation is perhaps the fastest growing use for MT. (1997, p. 29)

Twenty years later, Melby's statement still rings true. Mainstream users of MT are more interested in hurriedly getting the overall gist of a text than obtaining a publication-quality translation. Cronin further argues:

The proliferation of translation applications for smartphones in addition to the now almost axiomatic

2. Castilho et al. explain that "[n]eural models involve building an end-toend neural network that maps aligned bilingual texts which, given an input sentence $\mathrm{X}$ to be translated, is normally trained to maximise the probability of a target sequence $Y$ without additional external linguistic information" (2017, p. 110). In short, neural MT builds on the abilities of statistical-based MT, in which algorithms are able to "analyze large collections of previous translations or parallel corpora to estimate what the statistical probabilities are of words or phrases in one language ending up in another" (Cronin, 2013b, p. 199). 
invitation to translate when Google searches throw up content in foreign languages are powerful multipliers for the practice of indicative translation.” (2013b, p. 199)

This suggests that many individuals, be they frequent users or mere witnesses, will be aware of these types of technologies and their limitations. It is precisely these limitations that Malinda Kathleen Reese and Urayoán Noel knowingly and willfully exploit for artistic purposes. Seeing technology as a creative force to harness, they use the undeniable shortcomings of MT (Reese) and voicerecognition software (Noel) as catalysts for their own creative ventures. They channel deficiencies productively, reappropriating linguistic material for their own artistic purposes. Such a view of translation as creation challenges the commonplace that translation is a purely semantic transfer that results in the (illusion of) identicality of source and target.

\section{Google Translate Sings: A Musical Reconfiguration}

Created in 2014, Google Translate Sings has, as of June 2017, gathered a following of some 475,000 YouTube users. Malinda Kathleen Reese's distorted comedic renderings of popular music have, in the popular parlance, gone viral, with many videos receiving more than a million views. Reese takes the lyrics of popular songs and puts them through several iterations of Google Translate, moving the lyrics through a variety of languages before retranslating them back into English. She then makes music videos in which she sings her translation on the original melody. Her sense of humour has clearly struck a chord with YouTube viewers. Reese has stated that on one hand, she "mock[s] online translation and its inability to be accurate" and that on the other hand, she "like[s] to celebrate the fact that language is weird" (Reese, 2015a, n.p.). She amplifies the inherent comedy in cross-linguistic communications - the fact that "when we try to communicate across linguistic and cultural barriers, we sound hilarious to one another" (ibid.) - with the help of readily available mainstream MT. The way in which she uses Google Translate is, of course, not how it was meant to be used. Reese fully acknowledges that fact; her willful misuse is measured and methodical, a process designed solely for the purpose of entertainment. 


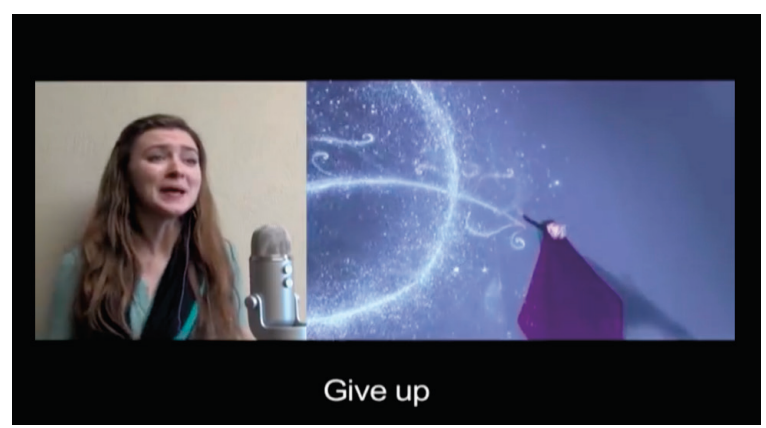

Figure 1. "Let It Go" from Frozen according to Google Translate (PARODY) (Reese, 2014a)

Reese's first Google Translate Sings video, uploaded on 10 February 2014, shows a roughly edited split-screen (see Figure 1). The right-hand side features a clip of the hit song "Let It Go" from the popular animated film Frozen (2013), whereas the left shows Reese singing her altered lyrics, which run as subtitles at the bottom of the screen. Reese prefaces her distorted karaoke with the following explanation:
If you put something into Google Translate, and you translate it into another language, and you try to translate that back into English, it's usually not what you put in the first time, and oftentimes, it's just not even close. (2014a, n. p.)

Based on a game Reese played with her friends, in which they would give this treatment to famous works of literature before enacting dramatic readings of the output, and after which "hilarity always ensued" (ibid.), Reese thought it would be just as funny to try with songs which would then be sung. Thus, the popular anthem of "Let It Go" became "Give Up," and the video went viral. Since then, Reese has produced 50 more Google Translate Sings videos (as of 8 June 2017), refining the process and improving production values. At its core, though, the process has remained much the same. She walks the fine line between absurdity and comedy by ensuring that her final product contains "something that your brain can recognize" (Reese, 2015b, n.p.). Reese states that she "translate[s] [lyrics] badly between languages in online translation programs so that they completely mess up and become 
nonsensical" (2015a, n.p.). Simple as it may sound, for Google Translate Sings, songs undergo a very calculated procedure; Reese does not simply feed the lyrics of the entire song into Google Translate and sing the output directly. Several steps-and indeed several iterations of MT-are involved. Continually questioned as to the specifics of her practice, Reese has produced a vlog entry detailing her process and her thoughts on translation (see Reese, 2015a). The manual segmentation she applies to the song lyrics, the number of iterations of Google Translate, not to mention the variety thereof, are all part of a process she has perfected to ensure that her parodies are as funny as they are recognizable. Her explanations illustrate that she has firm grasp of the workings of the technology and that she knows how to maximize the machine's effects for her specific purposes.

As a rule, MT uses segmentation because the systems are generally unable to process whole texts as single units (Cettolo and Federico, 2006, p. 664). The texts are thus segmented-split into smaller, more manageable chunks - and processed by the system prior to reassembly. However, when one actively intervenes in the process, as Reese does, short, decontextualized segments can also render more affected output. Reese segments the lyrics before she warps them with her process, which in turn more or less guarantees a bigger-and thus arguably funnier-distortion after she has recast them. With her systematic dismantling, transformation, and reassembly of words, Reese echoes the concept of "bricolage," which social anthropologist Claude Lévi-Strauss first outlined in The Savage Mind (1966 [trans. of La pensée sauvage, 1962]). This notion, i.e., the means by which people retrieve and recombine cultural materials to create new content, is exemplified in the way Reese plays with the material of the song-both in its visual representation (see Figure 2) and its linguistic rendition. Indeed, Reese harnesses technology for comedic purposes, consciously intervening in a technologically driven translation process that foregrounds playing with the linguistic material of the Other. Here, however, the material of the Other is not visible, as it is housed in Google Translate's vast multilingual databases, and thus hidden in the process of translation. 


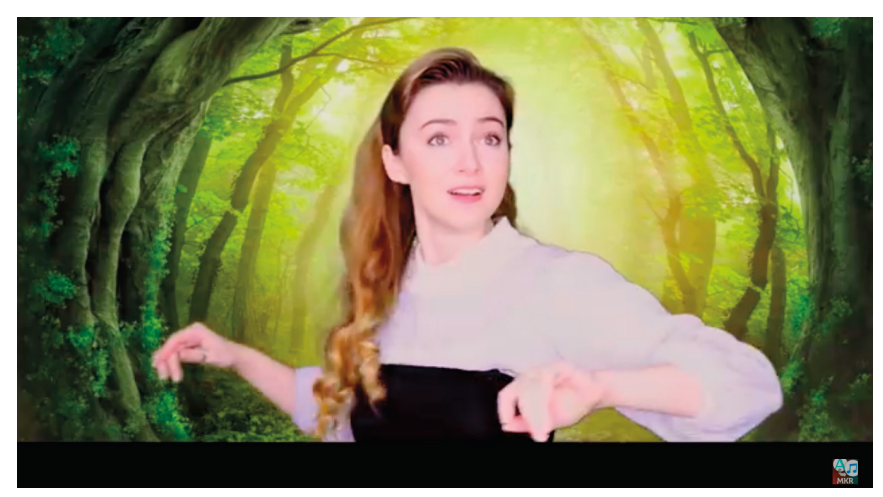

Figure 2. Google Translate Sings: Sleeping Beauty (Reese, 2016)

Interested in how cultures create entirely new solutions by reorganizing and using resources that already exist in collective social consciousness, Lévi-Strauss used the concept of bricolage to describe the characteristic patterns of the creativity displayed by the bricoleur, who will attempt to re-use available materials to solve new problems. Lévi-Strauss stresses that the
"bricoleur" is adept at performing a large number of diverse tasks; but $[\ldots]$ he does not subordinate each of them to the availability of raw materials and tools conceived and procured for the purpose of the project. His universe of instruments is closed and the rules of his game are always to make do with "whatever is at hand." (1966 [1962], p. 17)

The result of bricolage, thus, "is the contingent result of all the occasions there have been to renew or enrich the stock or to maintain it with the remains of previous constructions or destructions" (ibid.). Bricolage, in short, is a process of "tinkering" with the old to serve new purposes.

Originally presented as an analogy for processes of mythical thought-the selection of fragments from previous cultural formations, and their subsequent redeployment in new combinations - the idea of bricolage has been extrapolated and reappropriated by other fields. For instance, in cultural studies, the act of bricolage is seen as a form of intertextuality - the shaping of textual meaning or meanings by way of reference to other texts. Previously unrelated signs are rearranged and juxtaposed to create new meanings and unexpected associations, making bricolage a 
key stylistic marker of postmodern culture (Barker and Jane, 2016, pp. 237-238). Media studies theorist Mark Deuze (2006) argues that bricolage is one of the three principal components of digital culture, along with participation and remediation.

The bricoleur is generally portrayed as a jack-of-all-trades who uses few, non-specialized tools for a wide variety of purposes. Reese's creative misuse of Google Translate illustrates her expertise in bricolage: she exerts deft control over this "tool" that was developed for entirely different purposes, and wields it to achieve new goals. Her aim is the fragmentation and distortion of a wellknown cultural artefact-a song-which she then reassembles into comedic "Frankenstein's Monsters" for the enjoyment of her followers. ${ }^{3}$ More than the process, the product itself is also reminiscent of that of bricolage: a new whole made of pre-existing parts. The lyrics are changed, turned into anamorphic renditions of their source. Furthermore, the fact she sings her "creations" on the original melodies, adjusting if need be for the extra syllables, ensures that the public recognizes them as comedic distortions. She willfully exploits the foibles of the machine to destabilize the material of the original, warping it so each line becomes a barely recognizable parody of the original in the process.

Though several cycles of re-translation through Google would probably suffice to distort a song, Reese takes the added step of intervening in the process to ensure that each line is pushed to its comedic limit. She manually segments songs before she "feeds" the segments to the machine one by one, putting each through a number of translations-usually 5 or 6 (Reese, 2015a)—with different language pairings. The combinations she chooses, however, are not random at all: she deliberately selects language pairings for which relatively few bitexts are available for Google's MT system. For instance, her rendition of Sleeping Beauty's "Once Upon a Dream" is preceded by a list of some of the language pairings she used (see Figure 3, next page). The opening credits, so to speak, of the video explain what is to come, but the listed order and these pairings are only some of the ones she uses.

3. Reese's creative process is reminiscent of that of flarf poetry, in which poets often use Google search results as creative fodder; flarf poets, like Reese, end up creating "hilarious monstrosities" as artforms (Sullivan, 2011, n.p.). 


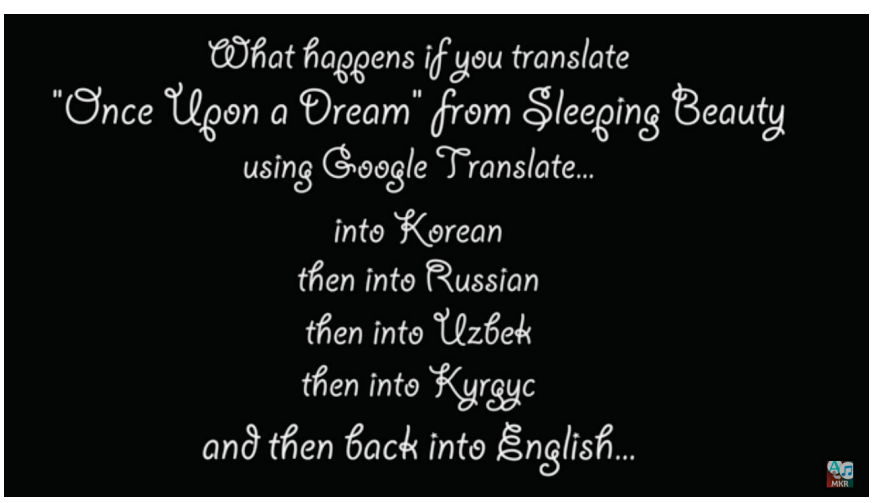

Figure 3. Google Translate Sings: Sleeping Beauty (Reese, 2016)

Reese's process is randomized to a certain extent, in that the layers through which she puts each segment might vary, both in kind and number, but the modus operandi is always the same. Urdu, Icelandic, Macedonian, Afrikaans, Nepali, Swedish, and Japanese are frequent players in Google Translate Sings' games because they form language pairings for which relatively few bitexts are available, and they share little in terms of syntactical structures or lexicon. The more linguistic discrepancy, the better, as the machine would be more prone to make mistakes, making those languages effective intermediaries, i.e., ones that can efficiently destabilize English syntactical structures. This method consistently turns recognizable lines from popular songs into artistically grotesque lyric re-imaginings.

These productions seem endlessly entertaining for Reese's followers, who share, comment, and "like" her creations by the thousands. The comedic effect of this technologically driven game of telephone (or Chinese Whispers) takes its full form with the juxtaposition of source and target in the final product. One of the most striking examples is the parodic translation Reese made of Miley Cyrus' 2014 hit song "Wrecking Ball."

The video's aesthetic is a nod to Cyrus' original, with slight modifications explained by the change in lyrics. Whereas Cyrus sings "I came in like a wrecking ball" while astride an actual wrecking ball (Figure 6), Reese-with her hair pinned up and back to echo Cyrus' pixie cut (Figures 4 and 5), wearing an identical shade of red lipstick and a very similar outfit-belts 
out "I like the ball in the sink" (2014b) with the same emotional commitment, swinging a baseball bat and dropping a baseball in a bathroom sink (Figure 7).

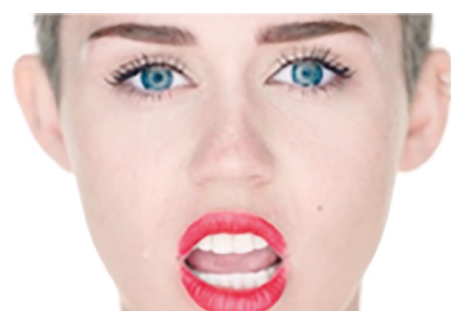

Figure 4. Miley Cyrus (2013), Wrecking Ball

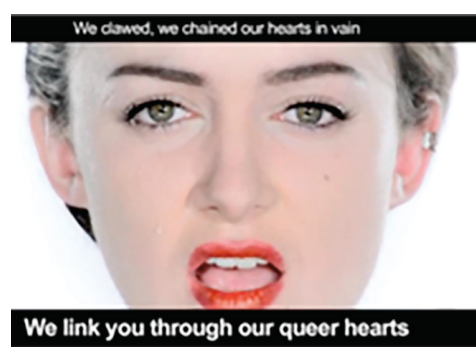

Figure 5. Google Translate Sings: "Wrecking Ball" by Miley Cyrus (PARODY) (Reese, 2014b)

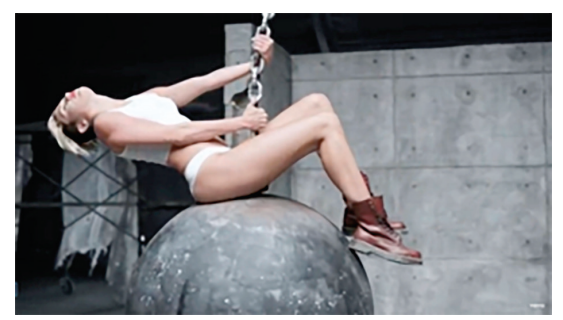

Figure 6. Miley Cyrus (2013), Wrecking Ball

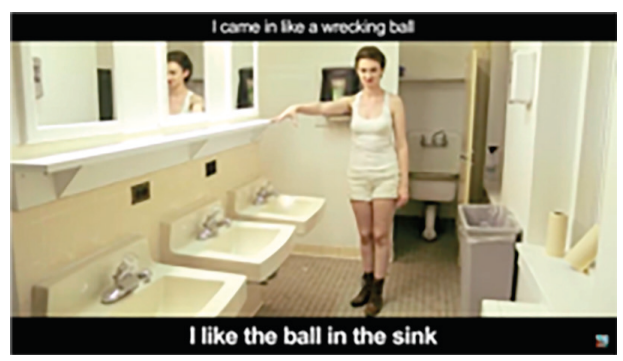

Figure 7. Google Translate Sings: "Wrecking Ball” by Miley Cyrus (PARODY) (Reese, 2014b)

The efforts that are put forth in referencing the original while at the same time enhancing the discrepancies are at the core of Google Translate Sings' comedy. The recognizable nature of the source and its mediated target are what both appeal to 
and cohere the in-group that is Reese's audience. According to Charlie Gere, the role of art is not to be a forerunner of social and cultural change in the digital age, but instead a kind of brake on it, "a way by which we can maintain a certain relationship to time through the experience of art" that "somehow counters the accelerated temporal development of these new technologies" (2014, n.p.). These forms of art "intervene in the $24 / 7$ ubiquitous social networks and general networks to somehow make us stop and pause, and think 'what's happened to us?" (ibid.). Therefore, the differences between the original songs and Reese's warped renditions-emphasized in the acting and singing-expose the fissures in the technological processes, and do so in a creatively productive fashion.

Reese's work can also be situated in relation to scholarship on contemporary literature. For example, in her 2010 monograph Unoriginal Genius, Marjorie Perloff explores the concept of citation in $21^{\text {st }}$-century poetry and its repercussions in the digital age. She bases her argument on the work of language philosopher Antoine Compagnon (La seconde main, ou le travail de la citation [1979]), and explores the "language of citation" (Perloff, 2010, p. 4). Her use of Compagnon appears to be motivated by the referential nature of poetry in the digital age, and explicitly considers the contributions of translation, which she describes as "the layering of languages" and as a form of "citational or intertextual poetics" (ibid., p.17). Other examples of this intertextual poetics include "the use of appropriated text, including archival material, documentary, informational manual, and, most recently, the discourse of the Internet from hypertext to blog to database" (ibid.). Perloff goes on to argue that "citationality, with its dialectic of removal and graft, disjunction and conjunction, its interpenetration of origin and destruction, is central to twentyfirst century poetics" (ibid.). Reese looks to Google Translate's databases as a potential source of "appropriated texts." The result is a form of citation that works on two levels-the algorithmic appropriation of linguistic materials during the process and the visual and aural reference to the source materials in the product on the screen-but only the latter is recognizable. The concept of citation has long played an important role in comparative studies, insofar as the field is concerned with tracing the relations between texts. 
Indeed, récriture, as Antoine Compagnon calls [citation], is the logical form of "writing" in an age of literally mobile or transferable text- text that can be readily moved from one digital site to another or from print to screen, that can be appropriated, transformed, or hidden by all sorts of means and for all sorts of purposes. (ibid.)

To return briefly to Deuze's principal components of digital culture, we can see that Reese illustrates all three: she 1) "participates" as an active creator and distributor of digital art, 2) "remediates" by transmogrifying old song lyrics and music videos in a citational process that parodies both the source material and the translation technology used to transform it, and 3) shows herself to be a "bricoleur" par excellence through her layered procedure of disassembly and reassembly of linguistic material, images, and sound. The viral success of her YouTube channel is perhaps the best indicator of her standing as a contemporary digital artist.

\section{Urayoán Noel's Computer-Assisted Homophonic Translations}

If Google Translate Sings provides an interesting example of digital-age bricolage, it does so with an emphasis on the written word, albeit with much visual and aural flare. The primary raw materials of Reese's art are the digitized song lyrics she chops up and then pieces back together with the help of MT. We would now like to consider a digital literary experiment that also evokes the notion of bricolage, but this time, the spoken word is the primary raw material, even as the written word continues to figure prominently. Homophonic translation is a practice from the margins of what one might define as translation; it is perhaps best known from the work of Celia and Louis Zukofsky (1969) and Luis d'Antin van Rooten (1980 [1967]). The homophonic translator works with the sounds of the source text and tries to map those source-language sounds onto similar sounds in targetlanguage words. The idea is to recreate the sounds, and not the meaning, of the source text. By working with signifiers, and not signifieds, the homophonic translator is working directly with the most "material" aspect of language. Although homophonic translation may sound like the archetype of identicality-with the source text simply becoming the translation-it moves entirely away from any semantic regime by jettisoning all attention to equivalence of meaning and focusing entirely on sound. 
Urayoán Noel is a poet, translator, and performer of mixed Anglo-American and Puerto Rican origin. His collections of poetry, such as Hi-Density Politics (2010) and Buzzing Hemisphere/Rumor Hemisférico (2015), showcase the results of experimental literary processes, including digitally mediated ones, with translation figuring prominently. For example, his collections include Google Translate creations, as well as poems composed on Blackberry voice notes and fashioned using an online Oulipean $\mathrm{N}+7$ generator and a smartphone anagram app. Both books also feature computer-assisted homophonic translations, in which source-text segments have been read aloud into a device with voice-recognition software set to the target language. Thus, Noel composed "trill set" (2010, pp. 69-81) by reading, in the original Spanish, the first 13 poems of César Vallejo's Trilce (1991 [1922]) into Dragon NaturallySpeaking voice-recognition software set to English. The result is a sort of computer-generated interlingual mondegreen. Table 1 provides an excerpt of "trill set," presented side by side with Vallejo's original.

\section{Table 1. "Trilce II" and "trill set II"}

Tiempo Tiempo

Mediodía estancado entre relentes.

Bomba aburrida del cuartel achica tiempo tiempo tiempo tiempo.

Era Era.

Gallos cancionan escarbando en vano. Boca del claro dia que conjuga era era era era.

Mañana Mañana.

El reposo caliente aún de ser. Piensa el presente guárdame para mañana mañana mañana mañana

Nombre Nombre.

¿Qué se llama cuanto heriza nos? Se llama Lomismo que padece nombre nombre nombre nombrE

(César Vallejo, Trilce (1991 [1922], p. 48)
Dimple Dimple

Mint UBS bank island to entice bone bubble lead on what they let chic dimple D. and both he and opium will

Data Data

Dida scans the owner is co-bundle in buying oh and I will be ethical to a data in data and data

\section{Montana Montana}

There are also cutting them down and said being such a say in the water coming out of Magana Magana Magana Magana

Gnome but Gnome

Casey JAMA one police analysts SingTel muddle me smoke about a sick Non-gnome but gnome buT

(Urayoán Noel, "trill set”, 2010, p. 70)

Trilce contains a series of difficult modernist poems in which Vallejo stretches the limits of the Spanish language, inventing words, altering syntax, using dialect. To draw on a term from 
Russian Formalism, Vallejo sought to "defamiliarize" language. ${ }^{4}$ In attempting to recreate the sounds of Vallejo's Spanish in English, Noel's experimental translation pushes defamiliarization ${ }^{5}$ to its limit (see Alarcón and Viñas, 2014), giving over part of the process to an algorithm, and creating a puzzling but playful English text. Notably, Noel does not include the source text for "trill set" in Hi-Density Politics. However, he notes that he also presents the poem as a performance piece for two voices, with "trill set" read alongside the corresponding excerpts from Trilce in Spanish or in Clayton Eshleman's English translation (see Noel, 2010 , p. 6). Thus, in performance, the translated poem is seen as so defamiliarized that it requires recontextualization through association to an original or to a more "traditional" translation. Indeed, homophonic translation achieves its fullest force only with juxtaposition of source and target, as was also true for Reese's translated lyrics.

Computer-assisted homophonic translation clearly explodes the bounds of semantic identicality. What is notable, however, is not that the result is a radical semantic disjunction between source text and translation; that was expected. Far more interesting are the contiguities between Trilce and "trill set." In reading the selection in Table 1 aloud, one may notice phonetic echoes

4. Michelle Clayton draws parallels between Vallejo's experimental poetry and Viktor Shklovsky's call to defamiliarize language through poetry, but notes that Vallejo himself was not likely familiar with the work of the Russian formalists, who were his contemporaries (2011, p. 293).

5. Richard P. Gabriel characterizes defamiliarization as central to his own experiments with harnessing the flaws of technological tools to create flarf and conceptual poetry. For him, defamiliarization is a "mechanism that frees the brain from its rational shackles" (2012, p. 134). He describes how he has used online translation software to tinker with well-known poetry and create experimental and conceptual works in turn: "My concept was to use Babelfish to make a set of ridiculous translations of the well-known poem in order to free it of its now-familiar wording. I had it translate the poem from English to Greek, then to Korean, then to Japanese, then to German, and back to English; I used a set of such cyclic translations as the starting point for the poem. This is conceptual art" (ibid., p. 140). Gabriel's poetic experiment recalls Reese's use of Google Translate and Noel's application of voice-recognition software. In all three cases, the art is "produced using human effort after or intertwined with machine assistance, and [...] the success of the result depend $[s]$ on the machine tools being flawed-or simply not very good" (ibid., p. 142). The awareness of the inherent weaknesses of the tools allows these artists to better manipulate the process. 
of the original in the translation. Consonants in particular are frequently reproduced by the software. For audience members, a primary pleasure in a bilingual performance of "trill set" would be the fleeting moments of recognition of acoustic echoes of the source text. In print, Noel nods to those familiar with Vallejo by intervening to maintain certain features of the source text, such as layout and some of the capitalization, including the surprising final capital letter of "Trilce II" (see Table 1).

Noel's computer-generated mondegreens illustrate much greater "phonetic drift" away from the sounds of the source text than perhaps a human-generated mondegreen would. This is because any type of voice-recognition software relies on a specific corpus of English words and phrases against which it attempts to match the sound patterns uttered by the user. In fact, the underlying algorithms do more than match sounds; they also attempt to match word sequences according to language models (see Huang et al., 2014). As with Reese, Noel's process reminds us of Lévi-Strauss's bricolage. He works with the materials and tools that are at hand-the source text, his own voice, and the voice-recognition software with its particular algorithms, English language corpus, and language models - to create something new. With Noel's algorithmic experiment, the question of the English reference corpus is key to understanding how the linguistic materials of the Other are transformed during the translation process. In an interview for the Radio Ambulante: Unscripted podcast, Noel himself highlights the effect of the reference corpus on his translation, framing it as a limitation of the software:

There are two ways to think about what I'm doing [with "trill set"]. One is a parody, but another is as, in a way, using Vallejo to parody the limitations of this software, Web 2.0 language, with its focus on the technocratic, with its focus on the utilitarian, with its focus on the values of the business world, all the stuff that I see Vallejo as opposing in his poetry. (Alarcón and Viñas, 2014, n.p.)

The speech-recognition software available to Noel for this project dates to 2010 and initially targeted users in the American hightech industry. It is therefore not surprising that many words that Perloff might qualify as citations of global techno-industrial babble show up. In Table 1, we see several occurrences of the 
word "data," alongside references to "SingTel" and to the Swiss banking conglomerate "UBS." The examples multiply throughout the translation. Among the most humorous is when Vallejo's line "Mejor estemos aquí no más" (1991 [1922],p. 51) becomes a send up of the all-powerful Apple corporation with "Mac OS X will suck enormous" (Noel, 2010, p. 71). In juxtaposing the source text with an odd, techno-babble-laden "translation," Noel manages to pay homage to Vallejo's linguistic playfulness while skewering the universalist claims of global businesses and in particular the high-tech industry.

As discussed earlier, bricolage is about the retrieval and recombination of cultural materials for new purposes. The concept finds renewed relevance in the information age, as large quantities of materials are readily available for tinkering by potential bricoleurs like Reese and Noel. Deuze also highlights the fact that "bricolage finds its opposite in originality" (2006, p. 67), as its very essence lies in the recycling of existing material for new endeavours. In homophonic translation, the translator (and in Noel's case the software as well) is recycling acoustic materials. While sounds, and more specifically the sounds of a language, are certainly a form of cultural material, one might ask whether other materials from the source culture survive or resurface in homophonic translation. Or perhaps it would be more accurate to ask whether a strict attention to sound allows room for other cultural elements to re-emerge as the target text is cobbled together. In an interview with the online newspaper the Rivard Report, Noel speaks to the importance of culture to his technologically mediated experimental poetics:

There is usually a cultural/social dimension to such experiments, even if they seem like gratuitous playfulness. For instance, [Buzzing Hemisphere/Rumor Hemisférico] includes a homophonic translation of a sonnet by Sor Juana Inés de la Cruz which was generated by reading her poem into a smartphone with voice-recognition set to English. I got the idea for that kind of experiment after watching my mom struggle with the voice-recognition software on her computer because it would misunderstand her accent. The idea that our accented, Spanish-tinged language could subvert neoliberal gadgetry was very much in keeping with the thrust and the spirit of the book. (Camp, 2016, n.p.) 
Noel has stated that one of his intentions in translating Trilce was to explore how he could bring his own culturally specific experiences to bear in the computer-assisted homophonic translation process (Alarcón and Viñas, 2014). One way to do so was in fact through accent. Noel intentionally varied his speech patterns when reading segments of the source text for the voicerecognition software, imitating, for example, the Anglo-tones of his father's Spanish or the Puerto Rican lilt of his mother's, and this variation in input led to greater diversity in output (ibid.). So, for Noel, his translation experiments are, in part, ways of exploring his own bilingual history and an attempt to infuse his work with remnants of the linguistic and cultural divide he lives in and around. Noel sums up these links in an interview with the online literary magazine Drunken Boat:

$[\mathrm{M}] \mathrm{y}$ interest in what I have called a practice of "nonequivalent" translation is surely linked to my experience of identity in and as a field of differences. (Schafenacker, 2015, n.p.)

If Noel is seeking to infuse his art with his own experience of identity, it seems relevant to ask what evidence his poetry contains of the field of differences established by his diverse background. We have already seen that family accents play a role in his digitally mediated translation process, but what of the resulting translations? How does the Spanish-language side of Noel's background come through in his homophonic English poems? With "trill set," the clearest answer is perhaps in the extensive presence of Spanish-language words, in particular proper nouns. We see one example in Table 1 with the repetition of "Montana Montana"-a state named for the Spanish word for mountain (montaña)—to translate "Mañana Mañana." Further examples include more geographic names, first and last names, and an occasional common noun: Montevideo, Florida, Columbia, Los Gatos, Espejo, Amiga, Loma, Octavio, Eva, Osvaldo, Rios, and mambo, among others. While an accent might subvert neoliberal gadgetry, the reading of lines of Spanish-language poetry into English voice-recognition software appears to reveal the extent to which Anglo-American culture is intertwined with SpanishAmerican history, culture, and language. Thus, the "unsuspected potentials" (Cronin, 2013a, p. 53) of Noel's voice-recognition 
software allow him to resist the universalizing impulse towards a global technocratic English while highlighting the intercultural nature of the Anglosphere and in particular the enduring presence of Spanish in the linguistic, geographic, and cultural specificity of the United States. His digital tinkering tests the limits of acoustic convertibility, but even in the total absence of any semantic regime of identicality, scraps of his own complicated identity infuse both his translational process and product.

As was the case with Reese, Noel's art also illustrates Deuze's three principal components of digital culture: he 1) "participates" in a highly personalized computer-mediated artistic process, 2) "remediates" modernist poems as quirky acoustic echoes that serve as both parody and homage for recirculation in print and performance, and 3) shows himself to be a deft "bricoleur" who draws on both digital databases and elements of his complex cultural and linguistic origins.

\section{Technological Experimentation as Radical Foreignization}

Because translation is inextricably linked to culture, questions of representation, power, and identity readily come to the fore, as we have just seen with Noel's poetry. The translator's position in regard to the source and target, both in terms of texts and of audiences, can never be devoid of ideological presuppositions. The translation space is necessarily charged with social and cultural contexts, and the translator is not granted a privileged position outside the possible frictions within the cultural dynamics. For that reason, translation studies shares with the field of ethnography an interest in foregrounding the roles of their agents in their respective writing processes. No text, whether the result of ethnography, translation, or any other writing practice, comes to be from a position of absolute neutrality. Strategies that foreground the presence of the author as writer-or, in our case, the artist as intervenor-push the formal conventions of writing from the inside. Specifically, with Reese and Noel, we see a form of countertactics of writerly experimentation made manifest in playful experimentation with, and wilfull misuse of, technology.

There is no sense that the artists we have discussed are trying to represent the Other in any substantive way. While most ethnographers and translators will strive to accurately "write the Other," Reese and Noel use the material of the Other to write. 
More precisely, the linguistic material of the Other becomes a lens through which they refract their selected source texts, all for the purposes of creative expression. As we have seen, parody looms large in their art. In her seminal work on the subject, literary scholar Linda Hutcheon describes parody as "one of the major forms of modern self-reflexivity" and observes that the "modern world seems fascinated by the ability of our human systems to refer to themselves in an unending mirroring process" (1985, pp. 1-2). However, if Reese and Noel are holding up mirrors to the works they translate, the mirrors are clearly cracked, as they test the limits of both parody and translation. Certainly, there is significant distance between their work and what most scholars conceive of as translation. Cronin argues that all paradigms of translation in the $20^{\text {th }}$ century "establish as their telos a notion of identicality: that the reader will experience the text as an original, in the full force of its expressive design" (2013a, p. 83). Neither Reese nor Noel see identicality as an end. Nor do they seek in any way to create a translation that readers will experience as an original. Instead, their translations are inextricably tied to the source texts, which themselves figure prominently in the performance of the translations. Their art becomes the embodiment of what Venuti might call a radical foreignization, illustrating variability to such an extreme that the target texts can no longer act independently. The full force of the expressive design of their translations is only realized in parallel reading with the original, emphasizing the "gaps" between source and target.

In "Translation, Simulacra, Resistance," Venuti argues that "[t]he critical force of [postmodern] translating necessarily depends on reception, on the audience's ability to perceive and comprehend the cultural political gesture that the translator aims to make" $(2008$, p. 22). If the translators' aim or gesture enacts a form of resistance, then the success of that resistance depends on the ability of the intended audience to grasp the intention. For both Reese and Noel, the expected similarities between source and target - the very ones that traditionally unify a variety of translations of the same source-are so obscured by the algorithmic interventions that they specifically require the artists to establish, for their audiences, other correlations between the source text and translation. These correlations rely, for Noel, on sound, graphic presentation, and parallel live performance. For 
Reese, they arise through a combination of melodic association and visual form. In both cases, the juxtaposition of the "translation" with the source text cements the association while at the same time calling attention to the processes that rendered the product. In short, their deliberate misuse of technology emphasizes translational processes that, for centuries, people have tried to hide. In doing so, the work of both Reese and Noel troubles contemporary notions of the possibility of a global language and the neatness of intercultural communication. Reese shows us how quickly semantic ruptures arise with the use of state-of-the-art MT technology, while Noel illustrates how the apparent presence of global business communication is ill-suited to translate the linguistic inventiveness and cultural specificity of poetry. At the same time, their work foregrounds the cultural and linguistic contiguities that persist even in translations that seek to enact radical ruptures with their source.

The formal experiments with technologically mediated translation led by both Reese and Noel challenge, intentionally or not, conventional understandings of the nature of translation and the inherent power dynamics within the translation process. They reappropriate the power ascribed to technology by purposefully misusing digital tools in an artistically productive way. Reese and Noel produce art that thrives on what Cronin calls "[ $t]$ he risk in prioritizing the role of tools" (2013a, p. 11). But rather than falling into a "trap of a techno-determinism which ignores the profoundly social nature of humans' interaction with each other and the world" (ibid.), their respective experiments showcase the possibility of a translational countertactics of resistance. Their work thwarts the universalizing tendencies of technology but also exemplifies the artistic fecundity of technological processes when human intervention acts as a guide. They reappropriate the power of the algorithm for artistic purposes, all while undermining its power by revealing-and emphasizing-its limitations. Power's authority comes from its capacity to remain invisible; once its workings are laid bare, its potency begins to dissipate. An examination of the work of digital-age artists such as Reese and Noel allows us to emphasize the unsuspected potentials of computer technologies, and to reconceptualize translation in a way that goes beyond fixed notions of what a translation should be or do in terms of fidelity and equivalence. As such, 
we are able to stop talking about difference as betrayal, loss, or misrepresentation, and focus instead on translation as a creative process that, at its core, involves tinkering with the material of language.

\section{References}

Alarcón, Daniel and Silvia Viñas, producers (2014). "Lost in Translation: Urayoán Noel Gives Poet Cesar Vallejo a Digital Makeover.” Radio Ambulante: Unscripted [Audio podcast, Public Radio International], 14 August. Available at: <www.pri.org/programs/radio-ambulanteunscripted/lost-translation-urayo-n-noel-gives-poet-cesar-vallejodigital> [consulted 17 February 2016].

Barker, Chris and Emma A. Jane (2016). Cultural Studies: Theory and Practice, 5th edition. London, SAGE.

Bau Gil, José Ramón and Anthony Pym (2006). "Technology and Translation (A Pedagogical Overview).”In A. Pym, A. Perekrestenko and B. Starink, eds. Translation Technology and Its Teaching. Tarragona, Intercultural Studies Group. pp. 5-19.

Camp, Alexandra van de (2016). "Gemini Ink: The Bilingual Buzz Behind Poet Urayoán Noel." Rivard Report, 1 March. Available at: $<$ therivardreport.com/the-buzz-and-bilingual-hum-of-puertoricanny-poet-urayoan-noel/> [consulted 25 May 2017].

Castilho, Sheila, Joss Moorkens, Federico Gaspari, Iacer Calixto, John Tinsley, and Andy Way (2017). "Is Neural Machine Translation the New State of the Art?” The Prague Bulletin of Mathematical Linguistics, 108, pp. 109-120.

Cettolo, Mauro and Marcello Federico (2006). "Text Segmentation Criteria for Statistical Machine Translation.” In T. Salakoski et al., eds. Advances in Natural Language Processing, 5th International Conference, FinTAL 2006, Turku, Finland, LNCS 4139. Berlin, Springer, pp. 664-673.

Clayton, Michelle (2011). Poetry in Pieces: César Vallejo and Lyric Modernity. Berkeley and Los Angeles, University of California Press.

Compagnon, Antoine (1979). La seconde main, ou le travail de la citation. Paris, Éditions du Seuil.

Cronin, Michael (2013a). Translation in the Digital Age. New York, Routledge.

Cronin, Michael (2013b). "Mind the Gap: Translation Automation and the Lure of the Universal.” TTR, 26, 2, pp. 193-218.

Cyrus, Miley (2013). “Miley Cyrus - Wrecking Ball.” Available at: <www. youtube.com/watch?v=My2FRPA3Gf8> [consulted 29 May 2017]. 
Deuze,Mark (2006). "Participation, Remediation, Bricolage: Considering Principal Components of a Digital Culture." The Information Society, 22, pp. 63-75.

Gabriel, Richard P. (2012). "Defamiliarization: Flarf, Conceptual Writing, and Using Flawed Software Tools as Creative Partners." Knowledge Management and E-Learning: An International Journal, 4, 2, pp. 134-145.

Gere, Charlie (2014). “DCRK Questions: Charlie Gere.” Centre for Digital Cultures. Available at: <https://vimeo.com/96915595> [consulted 1 June 2017].

Huang, Xuedong, James Baker and Raj Reddy (2014). "A Historical Perspective of Speech Recognition." Communications of the ACM, 57, 1, pp. 94-103.

Hutcheon, Linda (1985). A Theory of Parody: The Teachings of TwentiethCentury Art Forms. New York and London, Methuen.

Lévi-Strauss, Claude (1966 [1962]). The Savage Mind. Trans. George Weidenfeld. London, Weidenfeld and Nicolson.

Melby, Alan (1997). "Some Notes on the Proper Place of Men and Machines in Language Translation." Machine Translation, 12, pp. 2934.

Noel, Urayoán (2010). Hi-Density Politics. Buffalo, BlazeVOX [books].

Noel, Urayoán (2015). Buzzing Hemisphere/Rumor Hemisférico. Tucson, The University of Arizona Press.

Perloff, Marjorie (2010). Unoriginal Genius: Poetry by Other Means in the New Century. Chicago, University of Chicago Press.

Reese, Malinda Kathleen (2014a). "Let It Go' from Frozen according to Google Translate (PARODY)." Available at: <www. youtube. $\operatorname{com} /$ watch? $\mathrm{v}=2 \mathrm{bVAoV1FYf0} \&$ list $=\mathrm{PLGnYtw}$ ezZIBnVCUhMOcBqi9KggS1fhD\&index=1> [consulted 29 May 2017].

Reese, Malinda Kathleen (2014b). “Google Translate Sings: 'Wrecking Ball' by Miley Cyrus (PARODY)." Available at: <www.youtube. $\mathrm{com} /$ watch?v=zS-Gi5Z5zik\&index=4\&list=PLGnYtw5ezZIBnVCUhMOcBqi9KggS1fhD> [consulted 29 May 2017].

Reese, Malinda Kathleen (2015a). "My Real Thoughts on Translation." Available at: <www.youtube.com/watch?v=uRsKy9Rqa9M\&list=PL GnYtw5ezZI9LAMBUL0WFwiX6fv1nFG19> [consulted 29 May 2017].

Reese, Malinda Kathleen (2015b). "Q\&A: Kitchen-Sized Red Pandas.” Available at: <www.youtube.com/watch?v=qnedtaBtBMI> [consulted 29 May 2017].

Reese, Malinda Kathleen (2016). "Google Translate Sings: Sleeping Beauty." Available at: <www.youtube.com/watch?v=Lko0xM3w 
\&index=25\&list=PLGnYtw5ezZI-BnVCUhMOcBqi9KggS1fhD> [consulted 29 May 2017].

Rooten, Luis d'Antin van (1980 [1967]). Mots d'heures: gousse, ramesThe d'Antin Manuscript. New York, Penguin.

Schafenacker, Christopher (2015). "Interview with Urayoán Noel." Drunken Boat: An Online Journal of Art and Literature, 21. Available at: <www.drunkenboat.com/blog/?p=4931> [consulted 15 February 2016].

Snell-Hornby, Mary (2006). The Turns of Translation Studies. Amsterdam/ Philadelphia, John Benjamins.

Steiner, George (1998 [1975]). After Babel: Aspects of Language and Translation. Oxford, Oxford University Press.

Sullivan, Gary (2011). "A Brief Guide to Flarf Poetry." Available at: <www.poets.org/poetsorg/text/brief-guide-flarf-poetry> [consulted 27 November 2017]

Vallejo, César (1991 [1922]). Trilce. Madrid, Ediciones Cátedra.

Venuti, Lawrence (1998). The Scandals of Translation: Towards an Etbics of Difference. New York, Routledge.

Venuti, Lawrence (2008). “Translation, Simulacra, Resistance.” Translation Studies, 1, 1, pp. 18-33.

Zukofsky, Celia and Louis Zukofsky (1969). Catullus (Gai Valeri Catulli Veronensis Liber). London, Cape Golliard Press.

Stephen Slessor stephen.slessor@gmail.com

Anne Sophie Voyer anne.s.voyer@gmail.com 